\title{
Sequestered lumbar disc herniation mimicking spinal tumor
}

\author{
Pedro Radalle Biasi', Adroaldo Baseggio Mallmann², Paulo Sérgio Crusius², \\ Cláudio Albano Seibert², Marcelo Ughini Crusius², Cassiano Ughini Crusius², \\ Rafael Augusto Espanhol', Matheus Pintos Brunet ${ }^{1}$, Charles André Carazzo ${ }^{2}$
}

Faculdade de Medicina da Universidade de Passo Fundo (UPF), RS, Brazil, Instituto de Neurologia e Neurocirurgia, Passo Fundo, RS, Brazil.

\begin{abstract}
The occurrence of herniated disc simulating diseases in neuroimaging it's an uncommon situation. However, due to changes that occur in sequestered disc fragment, some cases can mimic spinal neoplasms. Thus, we present the case of a female patient, 60 year-old, with left back pain and left leg weakness. Left lower limb presented with strength grade IV, positive 45 degress Lasègue's signal and patellar areflexia. Lumbar spine magnetic resonance imaging (MRI) showed an expansive left centro-lateral lesion at $L 4-L 5$ level, hypointense on T1W, hyperintense on $T 2 W$, with peripheral contrast uptake, causing compression of the dural sac and $L 5$ nerve root. A hemilaminectomy was performed, with complete excision of the lesion. Histological analisys confirmed discal hernia. Disc herniation is a condition characterized by the displacement of the disc content to the spinal canal, predominantly in the lumbar region, and manifesting as radiculopathy. The fragment sequestration occurs in $30 \%$ of the cases and is characterized by loss of continuity with remaining disc. MRI exams generally allow diagnostic confirmation; however, there may be diagnostic confusion with tumors, arachnoid cysts and abscesses. The inflammatory reaction occurred in the disc fragment produces the differences in MRI signal. The fragment is hypointense on T1W, hyperintense on T2W, with peripheral enhancement after contrast. Malignancies and Schwannomas have homogeneous or heterogeneous uptake. The epidural abscess is isointense on T1W and hyperintense on T2W, with homogeneous or peripheral enhancement, similar to discal herniation. Thus, sequestered disc herniation can mimic other space-occupying lesions, being necessary a surgical approach to obtain material for histopathological analysis and diagnostic confirmation.
\end{abstract}

\section{KEYWORDS}

Intervertebral disc displacement, spinal cord neoplasms, nerve sheath neoplasms, lumbar vertebrae.

\section{RESUMO}

Hérnia de disco lombar sequestrada simulando tumor espinhal

A ocorrência de hérnias de disco simulando outras patologias em neuroimagens é incomum. Entretanto, devido às alterações que ocorrem no fragmento discal sequestrado, alguns casos podem mimetizar neoplasias espinais. Assim, apresentamos o caso de uma paciente do sexo feminino, 60 anos, com lombalgia à esquerda e fraqueza na perna esquerda. O membro inferior esquerdo apresentava força grau IV, sinal de Laségue positivo a 45 graus e arreflexia patelar. Ressonância nuclear magnética (RNM) de coluna lombossacra evidenciou lesão expansiva centrolateral esquerda ao nível de L4-L5, hipointensa em T1, hiperintensa em T2, com captação periférica de contraste, determinando compressão do saco dural e raiz de L5. Realizou-se hemilaminectomia com excisão completa da lesão. A análise histológica confirmou hérnia discal. Hérnia de disco é uma patologia caracterizada pelo deslocamento do conteúdo discal para o canal vertebral, predominando na região lombar e manifestando-se como radiculopatia. O sequestro do fragmento ocorre em $30 \%$ dos casos e se caracteriza por perda da continuidade com o disco remanescente. Exames de RNM geralmente permitem a confirmação diagnóstica, entretanto, pode haver confusão diagnóstica com tumores, cistos aracnóideos e abscessos. A reação inflamatória ocorrida no fragmento discal produz as diferenças de sinal na RNM. O fragmento é hipointenso em T1, hiperintenso em T2, apresentando realce periférico após contraste. Neoplasias malignas e Schwannomas apresentam captação homogênea ou heterogênea. Os abscessos epidurais podem apresentar realce homogêneo ou periférico, semelhante às hérnias discais. Assim, hérnias de disco sequestradas podem mimetizar outras lesões ocupando espaço, sendo necessária abordagem cirúrgica com obtenção de material para análise histopatológica para confirmar o diagnóstico.

\section{PALAVRAS-CHAVE}

Deslocamento do disco intervertebral, neoplasias da medula espinal, neoplasias da bainha neural, vértebras lombares.

1 Resident in Neurosurgery, Departament of Neurosurgery, Hospital São Vicente de Paulo, Passo Fundo, RS, Brazil.

2 Neurosurgeon, Institute of Neurology and Neurosurgery, Departament of Neurosurgery, Hospital São Vicente de Paulo, Passo Fundo, RS, Brazil. 


\section{Introduction}

The occurrence of discal herniation mimicking other diseases in imaging it's an unusual situation nowadays, in view of advances in neuroimaging, particularly with the use of magnetic resonance imaging (MRI). ${ }^{1-4}$ However, due to changes that occur in herniated disc fragment, specifically in cases of sequestered fragment, some cases may mimic other disorders such as spinal tumors. ${ }^{1,2,5,6}$ Given this, we present the case of a patient with preoperatively suspicion of spinal tumor by imaging, which had their diagnosis confirmed as lumbar disc herniation after histological analysis.

\section{Case report}

Female patient, 60 year old, with complaints of low back pain with irradiation to left leg in the last 2 months, associated with weakness of the referred leg. The physical examination revealed muscle strength grade 4 in the left leg, Laségue test positive at 45 degrees and absent patellar reflex. Lumbar spine MRI showed a lesion at L4-L5 level, in center-lateral position, hypointense on T1-weighted (T1W) (Figure 1), hyperintense on T2weighted (T2W), with peripheral enhancement, leading to compression of the dural sac and L5 nerve root (Figure 2), being probably an extradural tumor. Surgical approach was performed through hemilaminectomy, with complete excision of the occupying-space lesion, with satisfactory improvement. Histological analysis confirmed the diagnosis of disc herniation.

\section{Discussion}

Intervertebral disc herniation is a well-known pathology characterized by displacement of the disc content beyond the limits of the intervertebral space. ${ }^{6}$ The disc sequestration occurs when the disc fragment it's completely separated from the parent disc, situation present in up to $30 \%$ of the cases. ${ }^{6}$ This condition is specially common in the lumbar spine, and is the leading cause of neuropathic pain in lower limbs in people between 20 and 50 years. ${ }^{5,6}$ Clinically manifests itself by low back pain radiated to the lower limbs, weakness and paresthesia of legs, which does not allow a distinction to other clinical disorders. ${ }^{6}$ At about $95 \%$ of cases the injury affects disc levels L4-L5 and L5-S1, with disc fragments being dislodged laterally, superiorly or inferiorly into the vertebral canal, or, rarely, to the intradural space. ${ }^{5-8}$

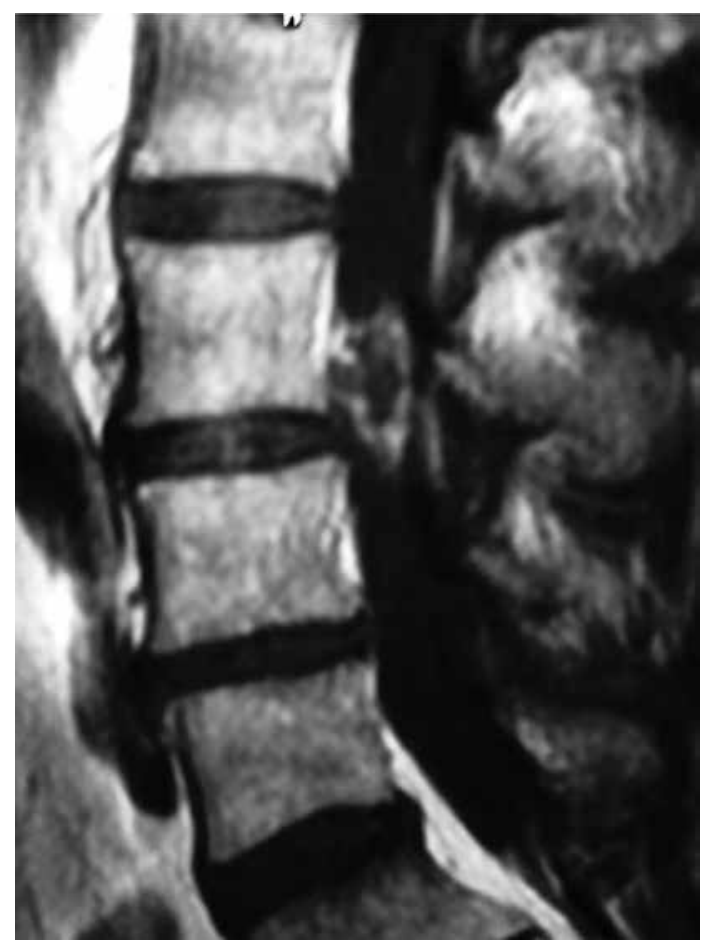

Figure 1 - Sagittal MR image, on T1W sequence with contrast shows the sequestered disc fragment with ring enhancement.

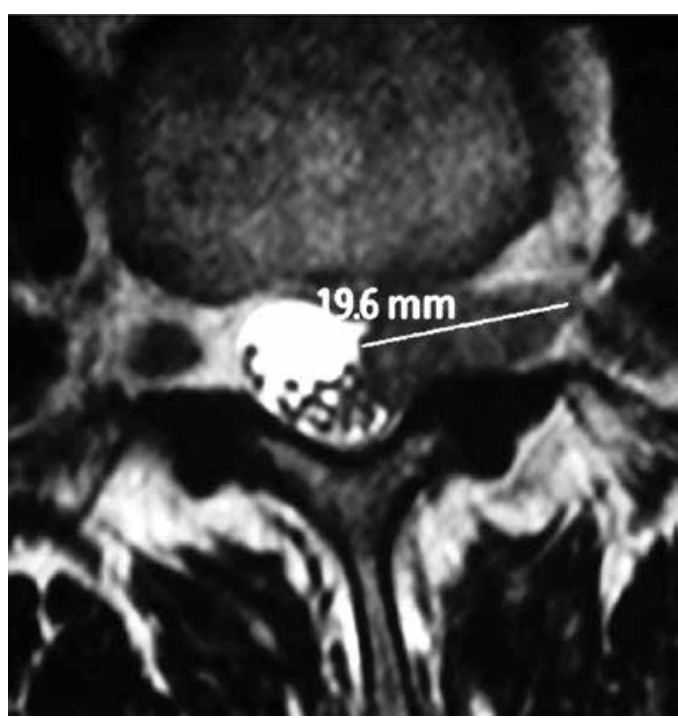

Figure 2 - Axial MR image on T2W sequence shows the hypointense disc fragment in left centro-lateral position, measuring $19.6 \mathrm{~mm}$ in the largest diameter and causing compression of nerve root and dural sac.

The diagnostic evaluation is usually done by MRI, which, in most cases, allows confirmation of disc herniation. ${ }^{1-5,7}$ However, in cases of sequestered fragment, it can be misdiagnosed as other pathologies and only surgical approach can confirm its origin. ${ }^{1-3,6,7}$ Differential diagnoses include neoplasms, such 
as chondrosarcoma, lipomas, meningiomas and malignant metastasis, arachnoid cysts, abscesses and infections. ${ }^{1-3,5,8,9}$

On MRI scans, sequestered disc herniation shows some characteristics that could lead to its suspicion and the contrast-enhanced phase could be the key to distinguish between disc herniation and tumors or infections. ${ }^{1,2,5}$ On T1W sequences, the fragment can range from moderate to hypointense, and on $\mathrm{T} 2 \mathrm{~W}$, it appears hyperintense to the pattern disc. After gadolinium infusion, its seen intense peripheral enhancement surrounding de non-enhanced disc, ${ }^{1,2,4,5,9}$ explained by inflammatory reaction and neovascularization around the sequestered disc fragment. ${ }^{2,4-6,9}$

Malignancies typically show homogeneous or heterogeneous uptake, and rarely ring enhancement. ${ }^{6,7}$ Chondrosarcomas may show moderate peripheral enhancement, but have lobulate architecture, differing from the disc fragment. ${ }^{6}$ As for the Schwannomas present homogeneous enhancement. ${ }^{2,6}$ Metastases commonly affect the adjacent bones and have a wide variety of signal. ${ }^{6}$ Nerve sheath tumors are isointense on T1W and hyperintense on T2W, with enhancement after contrast infusion, resembling the sequestered fragment, however, are primarily intra-dural, ${ }^{6}$ situation that occurs in only $0.3 \%$ of disc herniations. ${ }^{1}$

The epidural abscesses are usually isointense in relation to the spinal cord on T1W and hyperintense on T2W. After gadolinium infusion shows homogeneous or peripheral uptake, similar to disc herniations, which can lead to diagnostic confusion. ${ }^{3,5,6}$ The extra-dural hematomas may also provide contrast enhancement, but have trauma history associated. ${ }^{5}$

Still, there are situations where the disc fragment may show homogeneous enhancement, due to granulation tissue infiltration. ${ }^{4,5}$ Thus, the distinction between a sequestered disc herniation and malignancies or epidural abscesses can become a challenge, since the presentation to neuroimaging may be varied. ${ }^{3,5} \mathrm{In}$ such cases, only surgical approach to obtain material for histopathological analysis can provide accurate diagnosis. $^{3}$

Although uncommon, sequestered disc herniation can mimic tumors and other epidural occupying-space lesions, being difficult to distinguish in view of the variety of imaging presentation. Thus, the suspicion of disc herniation should always be kept in mind while investigate an epidural mass.

\section{Competing interests}

The authors declare no competing interests.

\section{References}

1. Aydin MV, Ozel S, Sen O, Erdogan B, Yildirim T. Intradural disc mimicking: a spinal tumor lesion. Spinal Cord. 2004;42(1):52-4.

2. Bakar B, Sumer MM, Cila A, Tekkok IH. An extreme lateral lumbar disc herniation mimicking L4 Schwannoma. Acta Neurol Belg. 2009;109(2):155-8.

3. Carvi y Nievas MN, Hoellerhage HG. Unusual sequestered disc fragments simulating spinal tumors and other spaceoccupying lesions. Clinical article. J Neurosurg Spine. 2009;11(1):42-8.

4. Lee JS, Suh KT. Intradural disc herniation at L5-S1 mimicking an intradural extramedullary spinal tumor: a case report. J Korean Med Sci. 2006;21(4):778-80.

5. Derincek A, Ozalay M, Sen O, Pourbagher A. Posterior epidural mass: can a posteriorly migrated lumbar disc fragment mimic tumour, haematoma or abscess? Acta Orthop Belg. 2009;75(3):423-7.

6. Hoch B, Hermann G. Migrated herniated disc mimicking a neoplasm. Skeletal Radiol. 2010;39(12):1245-9.

7. Joaquim AF, Ghizoni E, Cabral SR, Hamilton DK, Shaffrey $\mathrm{Cl}$. Unusual presentation of sequestered cervical disc herniation. J Bras Neurocirurg. 2010;21(4):239-41.

8. Omeis I, Cutler A, Das K, Chiles B 3rd. Sequestered high lumbar intradural disc herniation mimicking a spinal tumor: case report and review of the literature. Internet J Neurosurg [Internet]. 2006 [cited 2007 Nov 15];3(2). Available from: http://www.ispub.com/ostia/index. php?xmlFilePath=journals/ijns/vol3n2/herniation.xml

9. Sengoz A, Kotil K, Tasdemiroglu E. Posterior epidural migration of herniated lumbar disc fragment. J Neurosurg Spine. 2011;14(3):313-7.

Correspondence address

Pedro Radalle Biasi

Av. Sete de Setembro, 65, ap. 101

99010-120 - Passo Fundo, RG, Brazil

E-mail: pr.bias@@brturbo.com.br 